\title{
The effect of community mediations in the practice through an analysis of two municipal case studies
}

\author{
'We were born to work together, just like legs, arms and eyes, \\ like two jaws, the upper and the lower ones. \\ The restraint of each other is unnatural.'
}

Marcus Aurelius

\begin{abstract}
This study presents the continuously spreading municipal mediation in Hungary through two community mediations as good practice. It analyses theoretical and practical course of proceedings in community decision-making processes. It presents each practical phase of community mediations, analysing the practical effects of them. It compares them with other forms of decision-making, highlighting clear advantages of community mediation both for the leadership and the given community. Through presenting the process of two case studies, two model projects are analysed in details from the perspective of the municipal decision-making organs, civil organisations and the local population. In both presented cases different problems of the community are solved through the same process protocol.
\end{abstract}

Keywords: municipal problem solving, community mediation, organisation development, development of community communication, settlement mediation

\section{The background of progress in effective social decision-making forms}

Through the past decades the terms leadership and - together with that - decision-making are considerably changing all over the world. Instead of the earlier personal decision-making process as good practice, now emerged a decision-making process based on a wide exchange of information, share of knowledge before 
the final decision among the leader with authorization for decision and the organisations representing individuals affected in the given topic.

As a consequence, more exact and more effective solutions may appear, serving better for the concerned parties. In other words: 'The creation of new management forms (by the project partners) can be considered that these are in close connection to economic, social, cultural and / or physical transitions, through that several aspects of collective life can be organised on the given areas and settlements.'(Heinelt, Getimis, Kafkalas, Smith \& Swyngedouw, 2002).

In this paper decision-making meets fields of self-governments' decisions in connection with settlement development. The decisions on these fields have basic effects on the life of people with any activities (residents, workers, sportsmen, road users) in the settlement. These groups are normally organised into units by organisations, associations, expert groups, clubs - based on common activities. The representatives of the individual units are experts and people the best familiar with local conditions. We could also formulate, that these agents have the best preparedness, i.e., additional knowledge or connecting abilities (Horányi, 2007). These skills and this knowledge are not or not perfectly known in their coherences by local leaders, so they can only partially know the interests of the individual groups - and their reasons. The more groups/organisations are out of consideration in decisions on given projects, the higher is the chance of a dysfunctional operative result. So, it can be considered as a general rule, that accuracy in preparation of the individual project will determine the efficiency of the output (Ferik, 2014).

It depends on the perception ability of the leaders - in this case mayors - whether in case of certain conflicts a personal (power, authoritative) decision is taken, omitting a considerable part of people affected - ?and so additional knowledge and preparedness available through them only.

It is important to note that not a revolutionary leader's or decision-makers' change appears in the participation at decision-taking processes, and it cannot be assigned to the laissez-faire attitude either, you can only discover here the manifestation of the up-to-date, 21st-century version of a democratic leader's attitude according to Kurt Lewin: 'The democratic leader type: on contrary to authoritative leaders, democratic leaders include team members into the process of decision-making, but they meet the final decisions at the end. These leaders support creativity and the team members are committed to performance of tasks, so can be achieved good results, they are productive and workplace satisfaction is higher, too. The democratic leader style can be good applied in a considerable part of the organisation'(Lewin, 1997). 
In this solution process diversified and heterogenous aspects have to be considered usually, where it is easier and more logical to convene participants with appropriate skills on a given scene and at a given time. So, it gives the opportunity to get all aspects known. It is important to emphasize that preparedness not only means a special, e.g., lexical or practical knowledge but also aspects and experiences of the given organisation or organisational units, their future perceptions and goals in connection with the given topic.

\section{Long distance effects and sustainability of the process}

Environment protecting or environment conscious civic initiatives - and also other special civic initiatives - which mean proliferation of the classical term of civil society, emerged first at local levels (Heinelt et. al., 2002). Here it is an entrance of agents with global local knowledge - in comparison with the specified goals- into participative processes. I.e., not the concrete area of decision or one of its characteristics is important but the realisation of the well-defined and clearly scripted common communicative and decision-making process, which means a common agreement of the community based on a consensus.

These kinds of community mediations - just like successfully closed mediations - have a very high realisation and adherence rate. This means, that the participating parties respect the agreement even if they could not or only partially could assert their original perceptions, but they did understand and accept opportunities and limits of the given community. The most important element of the agreement is, that - after a community mediation - dysfunctional elements are rarely realised or conducted (if participants are included from the beginning.) The adherence rate is - in case of mediations with an agreement 91\% (Törzs, 2010).

The sustainability of this participative and consensus forming community mediation is given by the fact that the parties can correct their former agreement on the same scene again, in case of any changes in the environment or other conditions. Consequently, its content will not founder just change in its content. So can be e.g., a delay or withdrawer of a financial source, an act of God, and so on. That means, that the scene for creation of the decision will not be given up and that can sustain the opportunity to create an updated solution, too. 


\section{The effects of community mediation}

Workers in the organisation, as a community, comply the same job and function day by day. They are exporters and take decisions mainly in subtasks, which are not discussed by a wider public.

Community or participative mediations reveal preparedness of individual participants (employees, associates, members of an organisation, etc.) that cannot be experienced at an average job scene. Under scene we understand here that: 'it does not relate to circumstances of manifestation but to its possible 'interpretations', i.e., how the agent realises everything what is going on around.' (Horányi, 2007). It means practically in case of a community mediation, that the same person, who is an underling in everyday work, can add to the process of solution search and building interpretation, explanation and approach, that he cannot afford in every day's sphere. This preparedness and knowledge, which are present in the individuals but cannot be revealed at other occasions, are accumulating and forming the solution developed jointly. There are participants who bring just dynamic into the participative mediation group, and there are some bringing content information or others solution patterns gained by experiences elsewhere. Unconsidered the type of contribution to the common process, participants can overview other participants and so supposes will be replaced by common thinking and cooperation (Németh, 2014).

The efficiency of the process is given by interlocking of network-like thinking patterns, which have many outcome solutions. On contrary to authoritarian decision-making 'the chief will decide anyway' is usual at organisations. Guidance means influencing of several directions, while a chief is an authoritarian unidirectional connection (Algahtani, 2014).

The main difference between the two solutions is, that in case of decision-makings by one person the decision -making agent does not possess the following:

- a) Information relevant for the topic and influencing the outcome of decision-making.

- b) Interpretations and connotations connected to information, which can decidedly influence the rate of applicability of information.

At a participative decision-making the agents possess and share together the upper skills to the best of their knowledge. As a result of that the agents will create a common own world under mutual understanding of each other's reading. In this way, the commonly formed own world will include preparedness, skills and knowledge of those present. Beside them it contains desired needs and interests, which are sufficient for the agent to eliminate the problem. The common 
preparedness is available for each party (Horányi, 2007). It results in the new, together constructed and common own world, which make possible for the participating parties to define the difference/change causing the conflict among them. For the solution of the problem, based as above mentioned, the agents can use own or common sources, complemented and coordinated each other (Németh, 2019).

\section{The conditions for spread of good practices}

The community or participative decision-making offers considerable affirmation in the perspective of integrity of the organisation. Those people get involved, who will implement the result of the decision-making process. The decision is based on a consensus, so everyone will accept that, not just for the sake of the majority, but at least it is not against him, neither professionally nor ethically, so that it could make an identification impossible with that. It has an importance not only for content implementation, but it also means a paradigm shift in aspect of organisational problem-solving: The leadership of the organisation recognises and applies the fact, that the preparedness of the agents shared in a network system contains an additional knowledge, which cannot be activated at usual organisational conditions. It needs the precondition that the leader of the organisation or organisational unit trusts independent experts to handle participating community groups, who will then manage the process in given time frames (Németh, 2020).

So, the leaders of the organisation export control for a few hours or days but remain - in the majority of the cases - in the process as participants. The members of the organisation get another role in such cases, what they cannot settle in the organisation, due to their everyday role, because:

- The connection and communication to the leadership is decisive for their subsistence.

- The roles in the usual organisational environment do not make possible for the agent to present the own world - he cannot express the own skills, knowledge and preparedness in a self-identified way.

During the process are not only individual skills of the agents activated, but they also interlock and get into interactions. On contrary to an everyday work conference or brainstorming the participants think, do and accept proposals isolated, according to their workplace role and position; at a community mediation they can make proposals and give information on their standpoints, etc. as a fully adequate member of the group. A wider spectrum of ideas can freely 
interlock for a solution in any constellation. Further it can be also transformed, developed, etc. A network cooperation can multiply the efficiency of the pursuit of a solution in this led and supported process both in content, and in time. It is important to emphasize that this process cannot be carried out under normal organisational conditions. The workplace, as an institution, is the scene of visualisation of several interpersonal relationships. On the one side it is the scene of actions of employees on the given workplace according to developed and expected protocol. On the other side it is also the scene of private interpersonal connections, developed under interconnected and frequently interrelated duty cycles. The two processes (normal organisational mode of operation, participative consensus building in community) indicate perfectly different communicative structural units - they function alongside of absolutely different organisational and structural regulations. Simultaneously, it is important to note that the latter one can be a useful supplement and indicator of the previous one (Németh, 2018). Community mediation can be similarly a supportive process of building and strengthening organisational integrity at public workplaces, as it is well exemplified at self-governments.

The community mediation at organisational scene is one of the most widespread and most effective method to settle disputes in a community. Mediation itself appeared in the Hungarian Civic Law with entering into force of the Act no. LV of 2002 On mediator activity (URL2; Vékár, 2013). In the first few years beside relationship mediations, community mediation took an always greater space. We can differ several versions of community mediation according to characteristics of the individual fields, e.g., settlement, school, etc. (Németh 2020).

One of the most complex form of community mediation is settlement mediation, where many participants are met in questions of a given settlement. The representatives of more local offices, civil organisations, occasional or permanent communities of interest may complete the circle of invitees in this type. Beside the apparent complexity the practical experiences show that it can be considered as one of the most effective type of mediation. From the second half of the 2000s also state budget organizations (OBMB) supported and cooperated in this kind of mediations by applications. An example for that is the case study of Nagymányok, too.

\section{Case studies}

Two Hungarian cases are presented in the following. In the first case community mediation has been used in Esztergom exclusively as a conflict-handling and 
consensus-building protocol applied by external operators. In the Nagymányok project - which was supported by the National Crime Prevention Council - the representatives of local organisations acquired methodology of conflict handling beside the complete application, and so it can be applied also in other cases later on.

\section{The community mediation in Esztergom}

In several historical districts of Esztergom, the considerable re-arrangement of the traffic caused big scandal for the population (URL3, MTI, 2011), this change was captured in a decree of the self-government. In the opinion of citizens and local organisations the changes were not reconcilable neither with local, traffic nor with environment protection interests. Many personal and professional insults did not make possible a dialogue with the leaders of the city.

\section{Aims set in the project}

The Association Consensus Humanus was asked by the architect general of the Self-Government of Esztergom to organize a community mediation in order to solve the conflict situation dividing the city.

According to him the Self-Government of Esztergom have had a deficient and bad communication. The problems of communication were manifested, causing difficulties both in the inner function of the office and in its connection with the outworld. During the past years many developments and infrastructural changes without priorities had been formulated for the historical districts of Esztergom, but real resistance and scandal caused the full reorganisation of the traffic, especially the transformed traffic order in the districts Szenttamás, Szentgyörgymezö, and further Víziváros and Royale District. A full revision of that was necessary to be able to form a unified system of practical life circumstances and local habits. The representatives of state and civil organisations participated at the mediations, representing the population. The organisations of the city were represented by more than forty persons.

\section{Preparation}

Organisations with active preparedness about traffic interests of individual local groups were invited, so e.g., the town bikers' association, the drivers' association, 
the public traffic company, the representatives of educational organisations on the given area, etc. A preparation mediator contacted the organisations with relevant preparedness, who got support on one side from the self-government to reach interested parties and on the other side the interested parties informed him about attainability of representatives of further organisations considered important for the case. This gave the mediator the opportunity for a professional prefiltration, so that only organisations with relevant preparedness and affected by the topic of the mediation appeared. Beside reconciliation of a common timing each participant was informed about the duration of the mediation, which took normally four to six hours. In the case of Esztergom each occasion took about five hours.

\section{First community mediation}

At the first occasion the mediators gave information about goals, duration and exact timing of the mediation. As a second step, the representatives of the organisations met in a big circle in the festive hall of the Mayor's Office and individually informed the others who they are and whom they represent, in which part of the process they are met and have preparedness first of all in the topic, change of the traffic order in the city.

As a next step - because of the high number of participants - five working groups were formed by the mediators, so that representatives of traffic, educational institutes, civil traffic organisations and associates of the self-government were proportionally present in each working group. These heterogenous working groups noted separated on flipcharts in several points the traffic problems of the city and then classified them. In the third part, the groups shared their own lists with the other groups and formed a big common list, involved each participant. This list was then evaluated by the participants - sometimes agreed without further questions, sometimes argued further, but in each case was an agreement with consensus achieved. After finalisation of the evaluated list, the participants were satisfied with application and efficiency of this technic.

\section{Second community mediation}

The second session took place two weeks after the first one, with the same participants, mediators and regulations. In the common opening circle, each participant could give feedback, or add something to the previous occasion, resp. 
they could share proposals to newly emerged topics after the first occasion. As a second step, the participants were divided again into the similar workgroups like at the first occasion. The task was this time to give proposals for the registered problems, which can be realised without considerable financial investment and support the goals of the whole community (city). The self-government did not have a special source for this goal available, so that problems could only be solved e.g., with replacement of traffic sights, resp. with repainting of road markings. In the third session the work groups informed about the solutions worked out and compared them with solutions of other groups for the given problem. Also here was the solution registered in the list of solutions, which were considered to be the best by the whole group. Acceptance or refusal of the individual solutions did naturally influence the solution of other problems, too. Therefore, certain questions were occasionally discussed again or two separate problems were contracted. Both the participants and the traffic department of the city - i.e., the purchaser -have received the final list. The implementation did not cause any financial problems for the city, as the participants had already taken it into consideration during the community mediation.

\section{Follow-up: Results and sustainability}

The mediation of Esztergom got a nationwide publicity, both the leadership of the city and the participating organisations or the processing associations have received clearly positive feedbacks both about the high efficiency of the implementation and about the applicability of the method. The exact implementation of the changes was not made public by the city. But it has been proved that the applicability of the method was not limited by the number of participants or the size of the city. It is further independent from diversity or complexity of the problem, as the list of the elaborated solutions at the mediation in Esztergom included nearly fifty items. Each participating organisation worked in this process - appreciating the community of their own city - with high preparedness and active operations.

\section{The community program in Nagymányok - education and mediation}

In the following case the author was one of the participants, the description was made by the project manager, Dr. Zsuzsa Barinkai, and this was published 
in Issue 67 of Krimonológiai Szemle in 2010. The following reviewer equals in a considerable part with this case description - as they meet the same case.

The application under the title 'Variations to solve community conflicts in Nagymányok' obtained the support of the National Crime-Prevention Council (URL4). The project was realised under cooperation of the law office 'Vajna és Szotyori-Nagy Ügyvédi Iroda', the self-government of Nagymányok and the benefit association of the micro-region 'Életút Kistérségi Közhasznú Családsegítö Egyesület'.

Nagymányok is a village with 2640 citizens in the county Tolna, near Bonyhád. In its development played an important role: culture, financial knowledge, advancement of the German people settled down in the village and further mining beginning at the turn of the century. These two elements realised a relatively well organised society, urbanized traditions and urbanized services in the village. In the attraction zone of Nagymányok are the villages Kismányok, Váralja, Izmény and Györe, for them is Nagymányok considered as a centre in healthcare, culture and finances. Nagymányok has primary school, art education institute, kindergarten, library, cultural home and sports hall. Beside the district officer of the police also a civil-defence organisation takes care of security in the settlement. In the village are nearly 30 civil organisations active (Barinkai, 2010).

\section{Goals set in the project}

The goal of the project was to realize that conflicts should be locally recognised, cleared, declared and solved. The presentation of means of communication, which help to handle community conflicts locally in Nagymányok, by application of own resources. The long-distance goal of the project was to build in community or participative communication into the toolbar of the citizens and to let them serve as pattern for the new coming generations.

Conflicts emerged at several levels in the settlement:

- There was a common notary office functioning together with the neighbouring settlement, which caused numerous conflicts and due to them the office has been closed. There was a willingness for a repeated cooperation but it was difficult to approximate standpoints. (Administrative leadership.)

- The elderly home of the neighbouring settlement and that of Nagymányok entered into a partnership but many communicative problems emerged during the common operation (Institute leadership). 
- In Nagymányok a coal mine had been working since the beginning of the 20th century, which was closed in 1965. The intention for reopening caused serious frictions in the settlement. (Job creation vs. local interests)

- The local school accepts problematic pupils from the surrounding settlements, too. This leads to continuous differences among the leadership of the school, the teachers and the parents. (Quality education vs. central school)

The program was built up - based on previous in-depth interview - from two parts:

- Training of alternative conflict-handling education and of community mediation

- Processing of real conflict situations - which also means practicing of previously learnt technics

Three trainers, mediators, participated at the project, included mediators trained earlier by a partner organisation (Életút Egyesület). In this project 18 persons (teacher, kindergartener, school principal, health visitor, social worker, policeman, civil-defender, public areas supervisory, president and members of parent-teacher association, members of pensioner club, associates of the mayor's office) participated at mediation training and further 16 persons at community mediations.

\section{Training of alternative conflict management and of community mediation technics}

Emphasis was put in the curricula on theoretical background, regulation, practice, fields of application of civil and criminal mediation and on transfer of experience. In case of any demand there were possible personal consultations with trainers. The civil mediation training had 17 and the criminal mediation training 16 attendants. Participants were quite different in their social positions: district nurse, cleaner, health visitor, workman, associate of the self-government, kindergartener, teacher, remedial teacher, social worker, policeman, civil-defender, etc. The satisfaction questionnaire distributed at the end of the training shows that the self-formulated expectations of the participant (to get to know new opportunities for a solution, to gain new knowledge, applicability, casual, open atmosphere) were satisfied. The participants informed about positive experiences, a good harmony of theory and practice. According to them, their connection to conflicts and to others, their attitude was changed. The supervision has shown that the participants gained well applicable practical knowledge. 
More of them could use the learnt technic at their workplace, in the family, in their wider environment, and stated that this fact was also for themselves surprising and beyond their expectations. They considered as a good result that a community had been formed.

\section{The processing of real conflict situations - the application of learnt technics}

During the in-depth interviews and the trainings turned out that the breakpoint in functioning of the settlement lays in default of community communication, in the information flow of civil organisations among each other's, and in their connection to the self-government and in evaluation and applicability of decisions of the self-government.

According to that the participants chose for topics of the community mediation the questions above. The participants played an important role in the organization, taking common decision about the question, who have to play roles in the community mediation. It has clearly shown that at this point of the project the participants realized the importance of the cooperation. Beside the persons participated at the trainings were present: the mayor, a member of the representative body, a representative of the self-government of the gipsy minority, the leader of the civil self-defence, the leader of the fire fighters, the leader of the miners' trade-union and a local entrepreneur, who is the leader of a lifestyle association in the village.

The proposals after the first round of mediation were as follows: it was useful to have a civil initiative to colligate all civil organisations, in a so-called umbrella organisation (e.g., Association for Nagymányok), and further was very useful for building a community if the village could find out - beside the many small celebrations - a so-called 'Village Day' dealing with local people and local specialities only. The participants of the conference decided that the proposals should be made public in a wider circle for a democratic decision, and therefore they decided to continue community mediation instead of the planned mediation in the school conflict.

\section{The second community mediation}

To the second community mediation the participant brought along the proposals of their own community, which were as follows: they rejected setting up 
a common umbrella organisation, but they considered it important that the civil organisations of the village worked together in the future in some way. Here they found out to set up a civil forum quarterly with the aim to offer connection for the civil organisations and other organizations of the village, to arrange common programs, to cooperate with each other. As a first step in this direction the Mayor's Office hosted such a meeting in the first week of June. In the agreement were detained in details deadlines and responsible persons for the production and posting of invitations, the content elements of the invitation were recorded, too. In the second circle the participants decided upon the received proposals that this civil forum will have to decide on the Village Day.

\section{Follow-up: Results and sustainability}

The proposals for sustainability were summarized at the closing conference. In order to have more information about the means of the alternative conflict handling in the area, the participants of the project considered the inclusion of wider target groups, divided into age groups, resp. recipient organisations. So, emphasis was put on the role of children and youth in dissemination of mediation. The documentary film on the local mediation case was also used for knowledge transfer.

Extra highlight was on the training of the members of civil-defence realised within own competencies. Decided was further the regular quarterly meeting of the civil organisations with representatives of the self-government. The participant expressed the demand to organise community mediation, to strengthen community connections once a year. The responsible person for that was chosen at the closing conference.

The documentary film produced in the frame of the application, was also used for spreading of alternative conflict-handling technics: it will be presented at civil panels, in adult education and at lectures about settlement mediations. Further, this film became curricula for several institutions of the higher education. The association 'Életút Egyesület', which has trained mediators among the members, has taken mediation into its scope of activities. In this way mediation can be practiced in an official form, resp. the members of the association can support and develop the communication of community mediation at a higher level than previously. The short deadline of the application limited the number of feasible cases - there were six independent mediations - but it is important that the process of learning could start, which will turn mediation as good practice into everyday technic. 


\section{Comprehension}

The community - or participative - mediation is a community communication method that has already been proved for decades, its application can be very effective to solve problems of communities and to handle conflicts within them. The application of this method in Hungary was made possible with the legal regulation of 2002 - in accordance with Directives of the European Union. As first areas of dissemination can be mentioned educational institutions of the state or of self-governments, characteristically secondary schools, where it has been used to solve conflicts among students and the school and to form good practices and protocols. The other field of application is to solve several challenges of settlements' self-governments, for a better cooperation with the local community and for the solution of common problems effecting each local citizen, and further for planning of future developments. The two examples presented in details in this paper confirm clearly the assumption of theoretic professionals, according to that the community solutions realized by an exterior leadership with appropriate knowledge are much more successful than one-person decision-making. Success means, beside outlining of generally accepted ways of solution, also transparency of decision-making and performance. The latter one will end uncertainty by the fact that events become traceable in a wide circle, decreasing considerably the opportunities for corruption in this way.

Based on the good practices mentioned above, the paper draws a parallel and outlines the opportunities of implementation of community (participative) mediation at state-owned companies. There are even two versions of applicability available, based on the examples at self-governments. On one side it is only applied in concrete cases, including exterior experts. On the other side there are opportunities to learn mediative thinking and to apply it independently.

In both cases the integrity advisor of the state-owned organisation has a key role in perception of necessity of the program, and in participation in the preparation in case that the program will be applied. The decision-making leader of the organisation gets the opportunity to find the most useful solution, with involvement of the community of employees affected in the case. 


\section{References}

Algahtani, A. (2014). Leadership and Management Different? Journal of Management Policies and Practices, 2(3), 71-82. https://doi.org/10.15640/jmpp.v2n3a4

Barinkai Zs. (2010). 'Variációk a közösségi konfliktusok feloldására Nagymányokon'. OBmB-pályázati tapasztalatok ['Variations on releasement of community conflicts in Nagymányok' Experiences in OBmB-applications]. Kriminológiai közlemények, 67(1) 35-40.

Christakis, N. A. \& Fowler, J. H. (2010). Kapcsolatok hálójában, Mire képesek a közösségi hálózatok, és hogy alakitják sorsunkat [In network of connections. What are community networks able to and how they form our fates]. Typotex.

Ferik T. (Szerk.) (2014). Konfliktuskezelési, mediációs módszerek alkalmazása a településfejlesztésben [The application of conflict handling and mediative methods in urban development]. Kiadvány.

Horányi Ö. (Szerk.) (2007). A kommunikáció mint participáció [Communication as participation]. Typotex.

Heinelt, H., Getimis, P., Kafkalas, G., Smith, R. \& Swyngedouw, E. (Eds.) (2002). Participatory Governancein Multi-Level Concepts and Experience. Wiesbaden GmbH. https://doi. org/10.1007/978-3-663-11005-7

Lewin, K. (1997). Resolving Social Conflicts: And, Field Theory in Social Science. American Psychological Association, Harper \& Brothers Publ. https://doi.org/10.1037/10269-000

Marcus Aurelius (2006). Meditations. Penguin.

Németh V. (2014). Mediation as Problem-Solving Scene in the Light of PTC. KOME: An International Journal of Pure Communication Inquiry, 2(1), 3-13. https://doi.org/10.17646/ KOME.2014.12

Németh V. (2018). A mediáció jellemzői felhasználási területei szerint [Characteristics of mediation according to fields of application]. Kultúra és közösség, 9(2), 21-35.

Németh, V. (2019). Mediáció: A Kommunikáció Participációra Alapozott Felfogása Szerint [Mediation: According to the Approach Based on Participatory Communication]. Jel-Kép, 9(1), 17-25. https://doi.org/10.20520/JEL-KEP.2019.1.17

Németh, V. (2020). A közelség végtelen: A mediáció mint problémamegoldó a PTC tükrében [Proximity is endless: Mediation as problem solver as reflected in PTC]. GlobeEdit International Book.

Vékás L. (2013). A Polgári Törvénykönyv magyarázatokkal [The Civil Code with explanations]. Wolters Kluwer Kft.

Szarvas H. (2019). Helyi Demokrácia Fejlesztés Magyarországon [Development of Local Democracy in Hungary]. Doktori Értekezés. Nemzeti Közszolgálati Egyetem.

Törzs E. (2010). A helyreállító igazságszolgáltatás európai jó gyakorlatai a büntetőeljárásban [European good practices of restorative justice in criminal procedures]. In Közvetitöi eljárás - mediáció - Magyarországon, felnött korú elkövetök esetén [Mediation procedure in Hungary in cases of adult perpetrators]. Igazságügyi és Rendészeti Minisztérium. 


\section{Online links in the article}

URL1: Befejezödött a közlekedési mediáció. http://onkormanyzat.mti.hu/hir/11655/befejezodott_a_kozlekedesi_mediacio

URL2: OBmB - TELEPÜLÉSI MEDIÁCIÓS PROJEKTEK 2008-2009. http://www.foresee.hu/ uploads/media/Hatteranyag1_telepulesikonfliktkezeles.pdf

\section{Laws and Regulations}

50/2013. (II. 25.) Korm. rendelet az államigazgatási szervek integritásirányítási rendszeréről és az érdekérvényesítők fogadásának rendjéről

2002. évi LV. törvény a közvetítői tevékenységröl

\section{Reference of the article according to APA regulation}

Németh, V. \& Szabó, Cs. (2021). The effect of community mediations in the practice through an analysis of two municipal case studies. Belügyi Szemle, 69(SI6), 73-88. https://doi.org/10.38146/ BSZ.SPEC.2021.6.5 